\title{
KARAKTERISTIK BUDAYA ORGANISASI, KEMAMPUAN ADAPTASI, DAN KINERJA USAHA MIKRO KECIL MENENGAH
}

\author{
Hg. Suseno T.W. ${ }^{1}$ \\ Aloysius Triwanggono ${ }^{2}$ \\ Fakultas Ekonomi, Universitas Sanata Dharma \\ (sen_t_wid@yahoo.co.id) \\ DOI: doi.org/10.24071/exero.2018.010105
}

\begin{abstract}
This research aimed to find strength of corporate culture characteristics, adapt culture, and performance of small and medium industries. This study involved 40 respondents of small and medium industries owner located in Melikan Klaten Jawa Tengah and Krebet Bantul Daerah Istimewa Yogyakarta. This research is conducted using a descriptive analysis and non-parametric correlation. The findings showed that 42,8 percent of small and medium industry owners were categorized in strong and very strong corporate culture, 47,5 percent possess a good adapt culture, and 50 percent of respondent admitted that they have higher performance. The other result showed significants correlation between corporate culture, adapt culture, and performances.
\end{abstract}

Keywords: corporate culture, adapt culture, and performances

\section{PENDAHULUAN}

Dalam pemahaman yang sempit suatu usaha/perusahaan didirikan hanya sekedar untuk memperoleh laba, melalui hasil penjualan yang semakin meningkat dengan biaya rendah atau minimal kenaikan biaya tidak tinggi. Namun bagaimana agar penjualan semakin meningkat tentu tidak sesederhana yang diperkirakan. Meningkatnya penjualan dari jenis usaha manufaktur yang menghasilkan produk berupa barang (goods) atau penjualan jenis usaha jasa yang menghasilkan produk berupa jasa (services), sebenarnya merupakan salah satu saja dari keberhasilan kinerja (performance) suatu usaha. Kinerja usaha inilah yang secara lebih luas memiliki makna, sekaligus dirasa lebih penting bagi dunia usaha, apa pun jenis dan skala usahanya. Shahzad (2012), misalnya, secara khusus meneliti hubungan antara budaya organisasi dan kinerja usaha.

Mengingat pentingnya hal tersebut, maka banyak upaya penelusuran tentang faktor-faktor apa saja yang dapat meningkatkan kinerja usaha. Salah satu hal yang menjadi atensi dalam penelitian ini adalah faktor budaya organisasi perusahaan (corporate culture) dan kemampuan adaptasi (adapt culture). Budaya organisasi 
dipahami sebagai kesepakatan bersama mengenai nilai-nilai yang mengikat semua individu dalam sebuah organisasi dan seharusnya menentukan batas-batas normatif perilaku anggota organisasi.

Budaya organisasi memberi efek kepada sikap dan perilaku individu dan secara umum kepada kinerja organisasi perusahaan dimana menjadikan fenomena yang atraktif sebagai bahan studi. Budaya organisasi menjadi sebuah sistem untuk kendali sosial dan dapat mempengaruhi sikap dan perilaku para tenaga kerja melalui penanaman nilai-nilai (values) dan keyakinan (beliefs) dalam operasi usaha (Flynn, 2001). Budaya organisasi juga telah menunjukkan adanya pengaruh langsung pada komitmen dan kepuasan pelaku usaha (Johnson, 1998 dan MacIntosh, 2010).

Menurut Robbin (2008), budaya organisasi memiliki fungsi antara lain: budaya menciptakan pembedaan yang jelas antara satu organisasi dan yang lain; budaya membawa suatu rasa identitas bagi anggota-anggota organisasi; budaya mempermudah timbulnya komitmen pada sesuatu yang lebih luas daripada kepentingan diri individual seseorang, budaya merupakan perekat sosial yang membantu mempersatukan organisasi itu dengan memberikan standar-standar yang tepat untuk dilakukan oleh karyawan; dan budaya sebagai mekanisme pembuat makna dan kendali yang membentuk sikap serta perilaku karyawan. Robbin dan Schein (2010) juga mengemukakan bagaimana pentingnya identifikasi karakteristik budaya organisasi, baik untuk individu maupun kepentingan organisasi perusahaan. Karakteristik budaya organisasi tersebut antara lain memberi identitas, fokus pada sikap dan perilaku orang, nilai-nilai, penyatuan unit, inovasi, pengendalian, pengambilan resiko, orientasi tujuan, orientasi pemasaran dan sebagainya.

Membahas budaya organisasi dapat dilakukan dari beberapa aspek, misalnya memahami pengertian/definisi, karakteristik, kemampuan adaptasi, fungsi dan pengaruhnya pada kinerja usaha. Sangat menarik untuk diteliti bagaimana identifikasi karakter budaya organisasi untuk usaha mikro dan kecil (small business). Selama ini pembahasan tentang budaya organisasi lebih pada paradigma perusahaan dengan skala menengah dan besar, memiliki puluhan/ratusan atau bahkan ribuan karyawan, dengan kendali manajemen yang memang lebih rumit tetapi jelas konsepnya. Hal ini tentu berbeda dengan skala usaha mikro dan kecil yang hanya memiliki beberapa tenaga kerja, bahkan pemilik usaha sekaligus sebagai tenaga 
kerja. Dari segi manajemen sumberdaya tidaklah rumit, namun mendapatkan karakteristik budaya perusahaan tentu tidak mudah, atau budaya yang dikembangkan menjadi sangat variatif bagi para pengusaha mikro dan kecil.

Mengingat aspek budaya begitu sangat luas dan bersifat multidimensional, maka diperlukan pembatasan dalam penelitian ini. Fokus dari penelitian ini adalah menggali/eksplorasi terhadap karakteristik budaya dari beberapa faktor utama yang dapat mendorong kinerja usaha industri kecil dan menengah. Selain itu, penelitian ini juga ingin mengetahui kemampuan adaptasi usaha mikro-kecil-menengah terhadap lingkungan eksternal bisnis dan non-bisnis. Hal ini bermula dari apa yang dikemukakan Schein (2010) tentang budaya organisasi yang dikatakan sebagai pembelajaran untuk mengatasi masalah adaptasi terhadap eksternal perusahaan yang dibawa masuk ke dalam internal organisasi. Diasumsikan, bila perusahaan sudah menanamkan budaya secara kuat maka lebih mudah untuk melakukan adaptasi terhadap perubahan lingkungan eksternal.

Saat ini para pengusaha menghadapi kemajuan teknologi yang sangat pesat, persaingan yang sangat ketat, dan percepatan globalisasi. Itu semua mengakibatkan terjadinya perubahan lingkungan yang sangat cepat dan sering tidak dapat diprediksi. Dalam situasi seperti itu, kemampuan berubah secara berkelanjutan menjadi sangat penting. Pengusaha, mirip seperti organisme, perlu tekun menjadi pembelajar yang terus berubah dan menyesuaikan diri dengan perubahan lingkungan bisnis yang dihadapinya (learning organization). Hal itu berarti, bahwa pengusaha harus menghidupi budaya adaptif (adaptive culture), suatu budaya yang mampu melakukan adaptasi. Schindehutte dan Morris (2001) menyatakan bahwa dalam konteks bisnis berskala kecil, kemampuan adaptasi menjadi lebih penting. Dibanding perusahaanperusahaan berskala menengah dan besar, perusahaan-perusahaan berskala kecil lebih rentan terhadap kekuatan-kekuatan eksternal, terutama karena cadangan kas yang terbatas, kapasitas utang, sering bergantung pada lini produk/jasa yang terbatas, dan kecenderungan untuk mengandalkan pada suatu basis pelanggan ceruk ( $a$ niche customer base). Banyak perusahaan kecil juga dirugikan karena hanya dapat melayani pasar yang relatif terbatas, mudah mengalami kerugian karena adanya fluktuasi permintaan yang signifikan, "perampokan" oleh para pesaing yang agresif, dan kurangnya dukungan dari para pemasok maupun perantara. 
Artikel ini mencoba mencari jawaban terhadap karakteristik budaya apa yang paling kuat bagi para pengusaha mikro-kecil-menengah, serta kemampuan adaptasi mereka untuk dikembangkan lebih lanjut dalam mendorong kinerja usaha. Secara khusus artikel ini bertujuan menganalisis kekuatan karakteristik budaya yang dimiliki para pemilik industri mikro-kecil-menengah; tingkat kemampuan adaptasi terhadap lingkungan eksternal bisnis dan non-bisnis yang dimiliki para pemilik industri mikrokecil-menengah; kondisi kinerja usaha para pemilik industri mikro-kecil-menengah; dan kekuatan korelasi antara karakteristik budaya, kemampuan adaptasi dan kinerja usaha para pemilik industri mikro-kecil-menengah. Asumsi yang digunakan untuk merumuskan masalah penelitian ini adalah organisasi dalam skala usaha mikro-kecilmenengah berbeda dengan usaha besar yang memiliki ratusan karyawan. Asumsi lainnya, tingkat kekuatan karakteristik budaya yang dipahami oleh para pemilik industri memberi peluang besar dari usaha mereka dalam melakukan adaptasi eksternal. Selanjutnya karakteristik budaya dan kemampuan adaptasi terhadap lingkungan eksternal akan mendorong upaya kinerja usaha.

\section{TINJAUAN PUSTAKA}

\section{Aspek Budaya Organisasi}

Pemahaman dan pembahasan tentang budaya organisasi perusahaan bisa berarti sangat luas dan panjang untuk dibahas, karena pada dasarnya membahas budaya berarti memperbincangkan soal kehidupan manusia itu sendiri, baik secara perorangan maupun secara kelompok/sosial.Pendekatan pemahaman budaya organisasi juga dapat dilakukan secara holistik dan multidimensional.Jadi budaya itu ada pada perorangan, kelompok, organisasi perusahaan yang intinya merupakan kebiasaan-kebiasaan yang dilakukan secara rutin karena adanya aturan ataupun dilakukan karena merupakan cara termudah untuk pelakunya melakukan pekerjaan.

Thrap (2009) mengatakan bahwa topik budaya organisasi memiliki pemahaman yang semakin meningkat sebagai aset perusahaan dan dapat digunakan untuk meningkatkan kinerja usaha. Menurut Thrap (2009) ada empat aspek budaya, yaitu invisible dan visible. Invisible terdiri dari nilai-nilai, sikap, asumsi dan keyakinan, sedangkan visible berupa artifak dan perilaku. Hal yang mirip juga dikemukakan oleh Anderson dkk. (2015) khususnya tentang attitude dan values. 
Khusus mengenai tipe budaya organisasi, Thrap (2009) membagi menjadi empat kategori, yaitu budaya kolaborasi, pengendalian/hirarki, menciptakan, dan kompetisi.

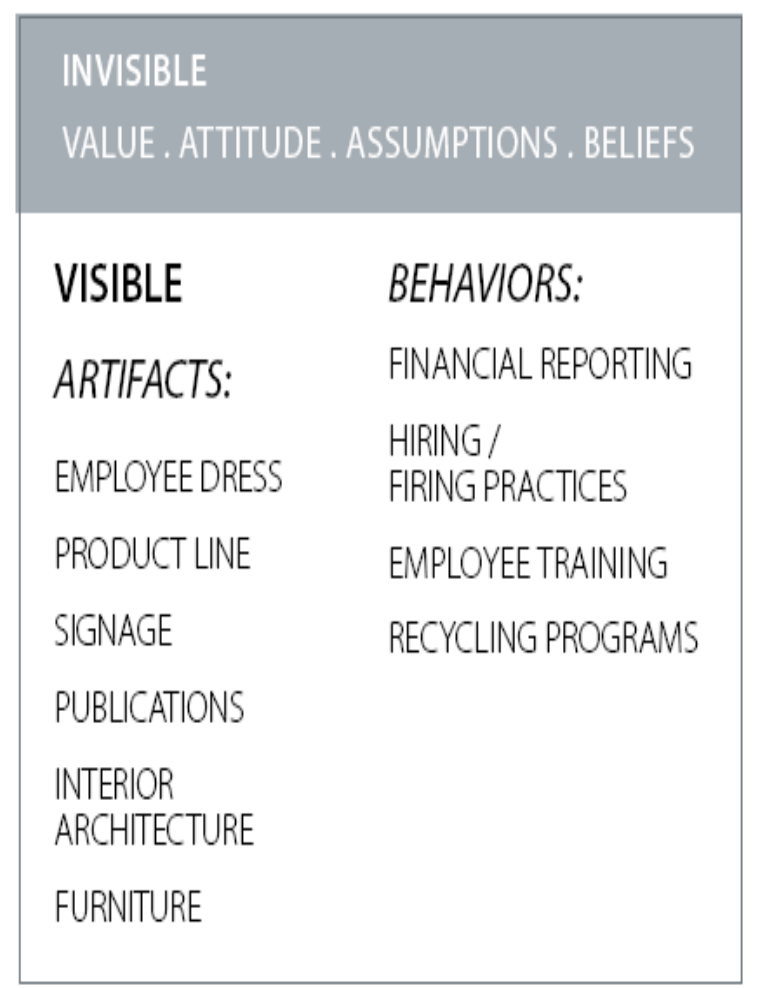

Gambar 1. Aspek-aspek Budaya

Sumber: Thrap (2009)

\section{Pengertian Budaya Organisasi}

Budaya dapat berupa peniruan atau keteladanan, penyerapan dari berbagai hal, ataupun peraturan yang ada dalam bentuk hukum atau pembelajaran, sehingga pelaksananya melakukan hal-hal tersebut sebagai suatu yang memang harus dilakukan. Pada akhirnya kegiatan yang terus menerus tersebut kemudian menjadi budaya kerja tersendiri bagi para pelakunya. Sebuah budaya dominan mengungkapkan nilai-nilai inti yang dimiliki bersama oleh mayoritas anggota organisasi. Tujuan dari budaya organisasi adalah untuk membangun sumberdaya manusia agar setiap orang sadar bahwa mereka berada dalam suatu hubungan sifat peran, mampu berkomunikasi secara efektif dan efisien (www.kompasiana.com).

Namun inti dari keberadaan budaya organisasi adalah bermanfaat bagi organisasi dan seluruh anggota organisasi. Apapun isi dan rumusan budaya organisasi, harus mudah dipahami dan semua anggota organisasi memiliki komitmen dan konsisten melaksanakan budaya organisasi, karena ituada istilah KISS (keep it 
simple and short). Sementara Drucker menyatakan bahwa karakteristik budaya organisasi adalah pokok penyelesaian masalah eksternal dan internal yang pelaksanaannya dilakukan secara konsisten oleh suatu kelompok dan selanjutnya diteruskan kepada anggota anggota baru sebagai langkah yang tepat dalam memahami, memikirkan dan merasakan terhadap masalah-masalah yang terkait dengan organisasi (www.butler-bowdon.com/peter-drucker).

\section{Budaya Organisasi dan Manajemen Usaha}

Menurut Schein (2010), budaya didefinisikan:

"culture is a pattern of basic assumption invented, discovered, or developed by given group as it learns to copy with is problem of external adaptation and internal integration - that has worked well enough to be considered valid and, therefore, to be taught to new members as the correct way to perceive, think and feel in relation to those problems."

Sementara itu, Robbin (2008) mengemukakan characteristics of organizational culture terdiri atas stability, team orientation, people orientation, outcome orientation, attention to detail, innovation and risk taking. Dalam kaitan ini, Jaghargh dkk. (2012) melakukan evaluasi terhadap tujuh karakteristik utama budaya organisasi menurut teori Robbin, yaitu variabel Innovation and Risk taking, Leadership, Integrity, Management support, Control, Identity, Rewards system, Compromise with conflict.

Bagaimana pun juga budaya organisasi secara umum diterima sebagai konsep yang holistik dan multidimensional, banyak peneliti telah menjelaskan bahwa budaya organisasi sebagai indikator faktor prediktif yang menentukan suksesnya sebuah organisasi. Itu berarti budaya organisasi menjadi penting karena banyak dilaporkan bahwa attitudes dan behaviors secara individu memberi dampak bagi kinerja perusahaan.

\section{Budaya dalam Usaha Mikro Kecil Menengah}

Pengertian tentang budaya organisasi memiliki pengertian (term) yang sangat luas tetapi nampak terlihat semakin ambigu (O’Donnell \& Boyle, 2008). Menurut 
Watson (2006), konsep budaya organisasi mengalami metamorfosa sebagai 'something cultivated'. Heskett (2013) mengatakan budaya memberi perbedaan dalam kinerja usaha: "can account for 20-30\% of the differential in corporate performance when compared with 'culturally unremarkable' competitors." Selanjutnya Coleman (2013) menjelaskan bahwa ada enam komponen dalam budaya organisasi perusahaan, yaitu visi, nilai-nilai, praktik, masyarakat, naratif, dan tempat.

MacDonald (2012) berpendapat tentang empat cara menangkap pengertian/pemahaman budaya organisasi khusus untuk usaha kecil, yaitu dari pandangan perspektif pemilik usaha, membangun pondasi dari keyakinan, menciptakan jalur-jalur terbuka untuk komunikasi, dan mengembangkan budaya perusahaan di luar jam kerja. Half (2016) mengemukakan peranan budaya perusahaan dalam usaha kecil, antara lain mempertahankan komunikasi dalam jangka pendek dan jangka panjang, dapat memotivasi usaha, menumbuhkan usaha secara cepat melalui visi yang dimiliki, dan mampu menolong pengembangan retensi. Guiso dkk. (2013) melakukan penelitian tentang dimensi budaya perusahaan yang terkait dengan kinerja usaha, seperti misalnya nilai-nilai, kepercayaan, tata kelola, dan integritas.

Rasmussen (2013) dalam penelitiannya menemukan bahwa ada hubungan secara signifikan antara budaya organisasi dan kesulitan melakukan perubahan manajemen perusahaan dalam rangka evaluasi. Hasil penelitian Jatmiko dkk. (2008) pada industri kecil tentang budaya organisasi, kepribadian pemilik usaha, strategi bisnis dan kinerja usaha, menunjukkan bahwa variabel-variabel tersebut saling mempengaruhi. Mircia dkk. (2012) melakukan penelitian tentang attitudes pemilik usaha sebagai budaya organisasi dan efeknya terhadap perubahan manajemen usaha.

Budaya organisasi juga dapat dikaitkan dengan kewirausahaan. Paunovic (2014) dalam penelitiannya mengemukakan bahwa salah satu elemen kunci dari kewirausahaan perusahaan adalah penciptaan budaya organisasi yang memadai yang mencakup nilai-nilai rujukanbudaya kewirausahaan serta faktor motivasi pelakuusaha, sehingga perusahaan dapat tumbuh dan berkembang.

Dari hasil penelitian Ramadan (2010) untuk industri kecil dan menengah, budaya organisasi memiliki keterkaitan dengan keunggulan kompetitif hasil produk suatu usaha. Budaya organisasi merupakan aset yang tidak bisa dibeli dengan uang, 
dan merupakan faktor yang dapat membuat sukses usaha atau menggagalkan suatu usaha.

\section{Kemampuan Adaptasi}

Menurut Denison (1995), teori adaptasi meletakkan penekanan pada kemampuan organisasi untuk menerima, menafsirkan dan menerjemahkan gangguan dari lingkungan luar ke norma internal yang mengarah pada kelangsungan hidup atau kesuksesan. Tiga aspek kunci dari kemampuan beradaptasiadalahpersepsi dan respon terhadap lingkungan eksternal, kemampuan untuk menanggapi pelanggan internal dan reaksi cepat baik terhadap pelanggan internal dan eksternal.

Menurut Schein (2010), lingkungan eksternal yang dihadapi perusahaan sebenarnya menjadi bagian dari dimensi budaya organisasi, apa pun skala usahanya, besar atau kecil. Proses pembentukan budaya organisasi yang kuat dalam jangka waktu lama akan membuat survive dalam beradaptasi terhadap lingkungan eksternal. Beberapa unsur yang esensial untuk beradaptasi menghadapi lingkungan eksternal perusahaan adalah mission and strategy, goals, means of developing consensus, reaching goals, measurement, and correction. Namun dalam penelitian ini budaya adaptif menggunakan konsep Denison.

Budaya adaptif dapat dinyatakan sebagai budaya yang mampu melakukan adaptasi. Menurut Schindehutte dan Moris (2001), adaptasi dapat didefinisikan sebagai tindakan-tindakan para pelaku usaha (entrepreneur) dan timnya dalam memproses masukan-masukan informasi dari lingkungannya dan membuat penyesuaian-penyesuaian yang cepat.

Kotter dan Heskett (1997) menyatakan bahwa perbedaan antara budaya perusahaan adaptif dan tidak adaptif terletak pada dua hal, yakni nilai inti dan perilaku umum seperti terlihat pada Tabel 1.

Tabel 1. Perbedaan Budaya Perusahaan Adaptif dan Tidak Adaptif

\begin{tabular}{|c|c|c|}
\hline Dimensi & $\begin{array}{c}\text { Budaya Perusahaan } \\
\text { Adaptif }\end{array}$ & $\begin{array}{c}\text { Budaya Perusahaan } \\
\text { Tidak Adaptif }\end{array}$ \\
\hline Nilai Inti & $\begin{array}{l}\text { Kebanyakan manajer sangat peduli akan } \\
\text { pelanggan, pemegang saham, dan } \\
\text { karyawan. Mereka juga sangat } \\
\text { menghargai proses yang dapat } \\
\text { menciptakan perubahan yang bermanfaat } \\
\text { (misalnya kepemimpinan ke atas danke } \\
\text { bawah pada hirarki manajemen). }\end{array}$ & $\begin{array}{l}\text { Kebanyakan manajer memperdulikan } \\
\text { terutama diri mereka sendiri, } \\
\text { kelompok kerja terdekat mereka, atau } \\
\text { beberapa produk (atau teknologi) yang } \\
\text { berhubungan dengan kelompok kerja } \\
\text { tersebut. Mereka menilai proses } \\
\text { manajemen yang teratur dan kurang } \\
\text { risikonya jauh lebih tinggi daripada } \\
\text { inisiatif kepemimpinan. }\end{array}$ \\
\hline
\end{tabular}


Tabel 1 (lanjutan). Perbedaan Budaya Perusahaan Adaptif dan Tidak Adaptif

\begin{tabular}{|c|c|c|}
\hline Dimensi & $\begin{array}{c}\text { Budaya Perusahaan } \\
\text { Adaptif }\end{array}$ & $\begin{array}{c}\text { Budaya Perusahaan } \\
\text { Tidak Adaptif }\end{array}$ \\
\hline Perilaku Umum & $\begin{array}{l}\text { Manajer member perhatian yang cermat } \\
\text { terhadap semua konstituensi mereka, } \\
\text { khususnya pelanggan dan memprakarsai } \\
\text { perubahan bila dibutuhkan untuk } \\
\text { melayani kepentingan mereka yang sah, } \\
\text { bahkan walaupun menuntut pengambilan } \\
\text { beberapa risiko. }\end{array}$ & $\begin{array}{l}\text { Para manajer cenderung berperilaku } \\
\text { agak picik, politis, birokratis. } \\
\text { Akibatnya, mereka tidak cepat } \\
\text { mengubah strategi mereka untuk } \\
\text { penyesuaian diri dengan atau } \\
\text { mengambil keuntungan dr dari } \\
\text { perubahan-perubahan } \\
\text { lingkungan bisnis mereka. }\end{array}$ \\
\hline
\end{tabular}

Sumber: Kotter dan Heskett (1997)

Lebih lanjut Marchand mengidentifikasi atribut-atribut dari budaya adaptif yang meliputi:

a)Semua karyawan, bagian, dan kelompok dalam organisasi unuk berkolaborasi secara efektif.; b) Kemampuan semua karyawan pada semua tingkatan untuk berjejaring dengan pihak-pihak di luar organisasi, memperoleh sumber-sumber baru dari informasi yang berguna maupun pespektif yang membantu dalam proses. Itu meliputi jaringan dengan konsumen dan pemegang kepentingan lain, tenaga ahli dari luar, bahkan dengan para pesaing.; dan (c) Kemampuan semua karyawan di segala tingkatan untuk berinovasi dan bereksperimen tanpa ada rasa takut.

Sebuah organisasi tentu tidak dengan sendirinya akan memiliki budaya adaptif seturut perubahan lingkungannya. Kemampuan adaptasi perlu diupayakan. Miller (2013) mengidentifikasi 10 cara yang dapat dilakukan untuk membangun budaya adaptif suatu organisasi: a)Menciptakan suatu perasaan krisis (a sense of crisis) dan adanya suatu kebutuhan bagi terjadinya perubahan dan arahan baru.; b)Berkomunikasi secara konsisten dan luas.; c)Menampilkan sebuah kecenderungan untuk menerima perubahan dan ide ide baru dari luar.; d)Memperkuat pentingnya inovasi.; e)Membangun dan memelihara kredibilitas pihak-pihak yang memiliki kepentingan.; f)Melembagakan focus yang seimbang pada keberhasilan konsumen, karyawan, dan pemilik.; g)Membangun kepemimpinan atau kemampuan untuk menghaasilkan perubahan sebagai focus penting pada semua tingkatan.; h)Mendesentralisasi pembuatan keputusan sejauh itu mungkin dilakukan.; i)Mempromosikan dengan hati-hati dan mendemosi jika dirasa perlu.; dan j)Bekerja sebagai pemimpin yang melayani. 
Kotter dan Heskett (1997) menyatakan bahwa jenis budaya adaptif menghargai dan mendorong kewiraswastaan, yang dapat membantu sebuah perusahaan beradaptasi dengan lingkungan yang berubah dengan memungkinkannya mengidentifikasi dan mengeksploitasi peluang-peluang baru. Kotter dan Hesket (1997) menekankan "pelanggan" dan menyatakan secara tidak langsung bahwa jika sebuah budaya sangat menghargai pelanggan, dan menciptakan perubahan untuk melayani kebutuhan pelanggan, akan membantu membuat sebuah organisasi menjadi adaptif. Butir-butir kuesioner untuk menilai adaptabilitas dari suatu organisasi pernah dikembangkan oleh Nesbit dan Lam (2014) yang dipaparkan pada tabel pengukuran (lihat metode penelitian).

\section{METODE PENELITIAN}

\section{Jenis penelitian}

Jenis penelitian ini adalah deskriptif non-parametrik dan bersifat eksploratif. Dikatakan deskriptif non-parametrik karena pendataan berupa paparan tabel dan kemudian dianalisis. Penelitian deskriptif menurut Widodo dan Mukhtar (2000) kebanyakan tidak dimaksudkan untuk menguji hipotesis tertentu, melainkan lebih pada menggambarkan apa adanya suatu gejala, variabel, atau keadaan. Statistika Non Parametrik untuk mengatasi pemecahan data yang memiliki ukuran sampel kecil dan asumsi-asumsi yang kurang dimiliki oleh peneliti. Statistika non-parametrik biasanya digunakan untuk melakukan analisis pada data berjenis Nominal atau Ordinal. Statistik nonparametrik banyak digunakan pada penelitian-penelitian sosial.

\section{Identifikasi Variabel}

Variabel pokok dalam penelitian ini adalah karakteristik budaya dan kemampuan adaptasi. Variabel karakter budaya perusahaan mengadopsi teori Robbin (2008), namun dimodifikasi dengan beberapa pendapat pakar mengingat bahwa usaha skala besar yang memiliki ratusan karyawan berbeda dengan usaha mikro dan kecil dimana jumlah tenaga kerja sedikit dan bahkan pemilik usaha sekaligus sebagai tenaga kerja. Karakter budaya teori Robbin dalam penelitian /survey menggunakan karyawan perusahaan sebagai responden, sedangkan dalam penelitian ini pemilik usaha menjadi responden. Adapun variabel kemampuan adaptasi terhadap lingkungan eksternal perusahaan menggunakan tiga dimensi Denison, yaitu 
penciptaan perubahan, fokus pada konsumen/pelanggan, dan pembelajaran organisasi perusahaan.

\section{Pengukuran}

Variabel dan instrumen pengukuran sebagai berikut:

Tabel 2. Pengukuran Variabel Karakteristik Budaya Organisasi

\begin{tabular}{|c|c|c|}
\hline No & $\begin{array}{l}\text { Indikator Karakteristik } \\
\text { Budaya }\end{array}$ & Instrumen Pengukuran \\
\hline \multirow[t]{3}{*}{1.} & \multirow{3}{*}{$\begin{array}{l}\text { Perspektif pemilik usaha } \\
\text { (perspective) }\end{array}$} & Memiliki kepribadian yang kuat melalui nilai-nilai yang diyakini \\
\hline & & Memiliki filosofi/visi yang diyakini dan menjadi arah usaha \\
\hline & & Memiliki cita-cita dan rencana ke depan \\
\hline \multirow[t]{2}{*}{2.} & \multirow[t]{2}{*}{ Motivasi usaha (motivation) } & Memotivasi diri dalam menjalankan usaha \\
\hline & & Tidak mudah putus asa bila mengalami kegagalan \\
\hline \multirow[t]{2}{*}{3.} & \multirow[t]{2}{*}{ Kepemimpinan (leadership) } & Merumuskan tujuan usaha dengan jelas \\
\hline & & Prioritas yang jelas dalam menjalankan usaha \\
\hline 4. & Integritas (integrity) & Memiliki rasa tanggungjawab dalam menjalankan usaha \\
\hline \multirow[t]{2}{*}{5.} & \multirow{2}{*}{$\begin{array}{l}\text { Inovasi dan Resiko } \\
\text { (innovasion dand risk } \\
\text { taking) }\end{array}$} & $\begin{array}{l}\text { Mencoba melakukan hal-hal baru, karena belum puas dengan hasil yang } \\
\text { ada }\end{array}$ \\
\hline & & Menyadari adanya resiko jika melakukan perubahan \\
\hline \multirow[t]{2}{*}{6.} & \multirow{2}{*}{$\begin{array}{l}\text { Komunikasi } \\
(\text { communication })\end{array}$} & Menjalin komunikasi dengan anggota paguyuban usaha \\
\hline & & Menjalin relasi dengan konsumen/pelanggan \\
\hline \multirow[t]{2}{*}{7.} & \multirow{2}{*}{$\begin{array}{l}\text { Koordinasi dan Kerjasama } \\
\text { (coordination\&cooperation) }\end{array}$} & Melaksanakan koordinasi dengan pengurus paguyuban usaha \\
\hline & & $\begin{array}{l}\text { Ada kerjasama dengan tenaga kerja/karyawan lain agar pekerjaan yang } \\
\text { dilakukan lebih efisien }\end{array}$ \\
\hline 8. & Identitas (identity) & Kesatuan/kebersamaan dalam bekerja \\
\hline \multirow[t]{2}{*}{9.} & \multirow{2}{*}{$\begin{array}{l}\text { Pengendalian usaha } \\
\text { (control) }\end{array}$} & Mengontrol produk yang dihasilkan \\
\hline & & Ingin selalu puas atas hasil produksinya \\
\hline 10. & $\begin{array}{l}\text { Penghargaan (reward } \\
\text { system) }\end{array}$ & Memberi penghargaan melalui imbalan yang layak kepada tenaga kerja \\
\hline
\end{tabular}

Sumber : Robbin (2003); Schein (2010), Heskett (2011), MacDonald (2012), Half (2016), dan Jaghargh et.all, (2012)

Tabel 3. Pengukuran Variabel Kemampuan Adaptasi

\begin{tabular}{|c|c|c|}
\hline No & $\begin{array}{l}\text { Indikator Dimensi } \\
\text { Kemampuan Adaptasi }\end{array}$ & Instrumen Pengukuran \\
\hline \multirow[t]{5}{*}{1.} & \multirow{5}{*}{$\begin{array}{l}\text { Penciptaan perubahan } \\
\text { (Kapabilitas Perubahan) }\end{array}$} & Cara melakukan segala sesuatu fleksibel dan mudah \\
\hline & & $\begin{array}{l}\text { Kami memberikan tanggapan baikterhadap para pesaing dan perubahan- } \\
\text { perubahan lain dalam lingkungan bisnis }\end{array}$ \\
\hline & & $\begin{array}{l}\text { Cara-cara baru dan cara-cara yang diperbaiki untuk melakukan pekerjaan } \\
\text { secara terus menerus diadopsi. }\end{array}$ \\
\hline & & Upaya untuk membuat perubahan biasanya menimbulkan penolakan (R). \\
\hline & & $\begin{array}{l}\text { Bagian-bagian yang berbeda dari organisasi sering bekerja sama untuk } \\
\text { membuat perubahan }\end{array}$ \\
\hline \multirow[t]{5}{*}{2.} & \multirow[t]{5}{*}{$\begin{array}{l}\text { Fokus Konsumen (Fokus } \\
\text { pada konsumen) }\end{array}$} & $\begin{array}{l}\text { Komentar-komentar dan saran-saran pelanggan sering menyebabkan } \\
\text { perubahan. }\end{array}$ \\
\hline & & $\begin{array}{l}\text { Masukan-masukan yang diperoleh secara langsung dari konsumen } \\
\text { mempengaruhi keputusan kami. }\end{array}$ \\
\hline & & $\begin{array}{l}\text { Semua anggota memiliki pemahaman yang dalam terhadap keinginan } \\
\text { dan kebutuhan pelanggan. }\end{array}$ \\
\hline & & $\begin{array}{l}\text { Kepentingan-kepentingan dari para pelanggan sering diabaikan (kurang } \\
\text { dipedulikan) dalam keputusan-keputusan bisnis kami (R). }\end{array}$ \\
\hline & & $\begin{array}{l}\text { Kami mendorong orang-orang kami untuk melakukan kontak secara } \\
\text { langsung dengan para pelanggan kami. }\end{array}$ \\
\hline
\end{tabular}


Tabel 3 (lanjutan). Pengukuran Variabel Kemampuan Adaptasi

\begin{tabular}{|c|c|c|}
\hline No & $\begin{array}{l}\text { Indikator Dimensi } \\
\text { Kemampuan Adaptasi }\end{array}$ & Instrumen Pengukuran \\
\hline \multirow[t]{5}{*}{3.} & \multirow{5}{*}{$\begin{array}{l}\text { Pembelajaran organisasi } \\
\text { (Kapabilitas pembelajaran } \\
\text { organisasi) }\end{array}$} & $\begin{array}{l}\text { Kami memandang kegagalan sebagai sebuah peluang untuk belajar dan } \\
\text { perbaikan. }\end{array}$ \\
\hline & & Melakukan inovasi dan mengambil risiko didorong dan dihargai. \\
\hline & & Banyak hal dalam organisasi kami "jatuh di antara celah-celah" (R). \\
\hline & & Belajar merupakan tujuan penting dalam pekerjaan sehari-hari kami. \\
\hline & & $\begin{array}{l}\text { Kami memastikan bahwa "tangan kanan mengetahui apa yang dilakukan } \\
\text { tangan kiri" }\end{array}$ \\
\hline
\end{tabular}

Sumber: Denison (1995)

Catatan: dimensi yang dinyatakan di dalam kurung merupakan nama yang dimodifikasi dalam riset, dengan alasan lebih mencerminkan perihal sifat dari dimensi.

\section{Populasi dan Sampel}

Populasi penelitian adalah para pemilik usaha industri mikro kecil menengah di dua lokasi, yaitu di dusun Melikan Wedi Klaten Jawa Tengah dan dusun Krebet Bantul DIY. Seluruh populasi di dua dusun sekitar 45 pemilik usaha dan akan dijadikan sampel/responden penelitian.

\section{Teknik Pengumpulan Data}

Teknik pengumpulan data yang akan digunakan melalui pengisian kuesioner. Kuesioner diberikan kepada para pemilik usaha dalam bentuk pilihan ganda dan isian singkat.

\section{Teknik Analisis Data}

Dari tabulasi data akan dilakukan analisis deskriptif terhadap variabel karakteristik budaya .

\section{HASIL PENELITIAN}

\section{Karakteristik Budaya.}

Heskett (2013) mengatakan bahwa budaya memberi perbedaan dalam kinerja usaha :"can account for 20-30\% of the differential in corporate performance when compared with 'culturally unremarkable' competitors. Itu bias diartikan bahwa keunggulan dalam bisnis sangat ditentukan oleh kebiasaan, budaya yang dikembangkan oleh sebuah institusi usaha atau entitas bisnis. Ada banyak pernyataan 
yang dapat dijadikan instrumen karakteristik budaya, dalam penelitian ini ada 18 item pernyataan (lihat tabel 3 ).

Tabel 4. Karakteristik Budaya yang terdiri atas 18 item pernyataan

\begin{tabular}{|c|l|l|l|l|l|l|}
\hline \multirow{2}{*}{ No. } & \multirow{2}{*}{ Pernyataan } & \multicolumn{5}{c|}{ Skala 1-5 (\%) } \\
\cline { 5 - 7 } & & \multicolumn{1}{|c|}{1} & \multicolumn{1}{|c|}{2} & \multicolumn{1}{|c|}{3} & 4 & 5 \\
\hline 01.00 & $\begin{array}{l}\text { Memiliki kepribadian yang kuat melalui nilai-nilai yang } \\
\text { diyakini }\end{array}$ & 0 & 2.5 & 12.5 & 50 & 35 \\
\hline 02.00 & $\begin{array}{l}\text { Memiliki filosofi/visi yang diyakini dan menjadi arah } \\
\text { usaha }\end{array}$ & 0 & 0 & 15 & 42.5 & 42.5 \\
\hline 03.00 & Memiliki cita-cita dan rencana ke depan & 2.5 & 0 & 5 & 32.5 & 60 \\
\hline 04.00 & Memiliki rasa tanggungjawab dalam menjalankan usaha & 0 & 2.5 & 2.5 & 37.5 & 57.5 \\
\hline 05.00 & Memiliki kesatuan/kebersamaan dalam bekerja & 0 & 2.5 & 7.5 & 40 & 50 \\
\hline 06.00 & Memotivasi diri dalam menjalankan usaha & 0 & 2.5 & 10 & 50 & 37.5 \\
\hline 07.00 & Tidak mudah putus asa bila mengalami kegagalan & 0 & 0 & 15 & 25 & 60 \\
\hline 08.00 & $\begin{array}{l}\text { Memberi penghargaan melalui imbalan yang layak } \\
\text { kepada tenaga kerja }\end{array}$ & 0 & 0 & 12.5 & 52.5 & 35 \\
\hline 09.00 & Merumuskan tujuan usaha dengan jelas & 0 & 0 & 10 & 57.5 & 32.5 \\
\hline 10.00 & Prioritas yang jelas dalam menjalankan usaha & 0 & 2.5 & 7.5 & 60 & 30 \\
\hline 11.00 & $\begin{array}{l}\text { Mencoba melakukan hal baru, karena belum puas dengan } \\
\text { hasil }\end{array}$ & 0 & 0 & 20 & 37.5 & 42.5 \\
\hline 12.00 & Menyadari adanya resiko jika melakukan perubahan & 0 & 5 & 5 & 52.5 & 37.5 \\
\hline 13.00 & Menjalin komunikasi dengan anggota paguyuban usaha & 5 & 2.5 & 17.5 & 50 & 25 \\
\hline 14.00 & Menjalin relasi dengan konsumen/pelanggan & 0 & 2.5 & 5 & 32.5 & 60 \\
\hline 15.00 & $\begin{array}{l}\text { Melaksanakan koordinasi dengan pengurus paguyuban } \\
\text { usaha }\end{array}$ & 5 & 5 & 22.5 & 42.5 & 25 \\
\hline 16.00 & $\begin{array}{l}\text { Kerjasama dengan pihak lain agar pekerjaan yang } \\
\text { dilakukan lebih efisien }\end{array}$ & 0 & 0 & 30 & 35 & 35 \\
\hline 17.00 & Mengontrol produk yang dihasilkan & 0 & 0 & 0 & 42.5 & 57.5 \\
\hline 18.00 & Ingin selalu puas atas hasil produksinya & 0 & 0 & 15 & 32.5 & 52.5 \\
\hline & $\begin{array}{l}\text { Rata-rata \% responden terhadap pilihan skala karakter } \\
\text { budaya }\end{array}$ & 0,5 & 0,9 & 11,8 & 44,2 & 41,5 \\
\hline
\end{tabular}

Sumber : Hasil analisis data

Kriteria skala :

1. Sangat lemah

2. Lemah

3. Cukup kuat

4. Kuat

5. Sangat Kuat

Secara keseluruhan (table 3), karakteristik budaya 44.2 persen berada pada skala 4 (kuat) dan 41.5 persen pada skala 5 (sangat kuat). Ini berarti 42,8 persen para pengusaha kecil di dua lokasi memiliki karakter budaya yang kuatdan sangat kuat. Kesinambungan organisasi sangat tergantung pada budaya yang dimiliki. Susanto (1997) mengemukakan bahwa budaya perusahaan dapat dimanfaatkan sebagai daya saing andalan organisasi dalam menjawab tantangan dan perubahan. Budaya 
organisasi pun dapat berfungsi sebagai rantai pengikat dalam proses menyamakan persepsi atau arah pandang anggota terhadap suatu permasalahan, sehingga akan menjadi satu kekuatan dalam pencapaian tujuan organisasi. Jadi intinya, karakteristik budaya perusahaan yang kuat dapat menjawab tantangan dan perubahan dan tentunya tujuan organisasi relatif lebih mudah tercapai.

Jika ditelusuri lebih lanjut (lihat tabel 4), kekuatan budaya para pengusaha kecil disumbang oleh tujuh hal yang menonjol melalui pilihan ukuran skala yang tinggi (skala 5 dan skala 4). Pilihan responden terhadap pernyataan memiliki cita-cita, tidak mudah putus asa, dan menjalin relasi dengan konsumen ada pada skala 5 masingmasing sebesar $60 \%$. Tiga hal ini dapat menjadi kunci kekuatan usaha kecil dalam menghadapi gelombang perubahan jaman.

Namun penelusuran secara umum bila dilihat darikontribusinya memiliki persentasemerata terhadap kekuatan karakter budaya (lihat grafik 1), namun mengontrol produk (15\%) dan menjalin relasi dengan pelanggan (15\%) memiliki persentasepaling besar dengan selisih tipis.Ini hal wajar mengingat control terhadap proses produksi sepenuhnya berada di tangan langsung pemilik usaha, bahkan mereka sendiri terlibat dalam proses produksi tersebut.

Tabel 5. Pilihan Responden terhadap Skala Kekuatan Budaya

\begin{tabular}{|l|l|c|c|}
\hline $\begin{array}{c}\text { No. } \\
\text { item }\end{array}$ & \multicolumn{1}{|c|}{ Uraian/pernyataan } & $\begin{array}{c}\text { Skala 4 } \\
\mathbf{\%}\end{array}$ & $\begin{array}{c}\text { Skala 5 } \\
\mathbf{\%}\end{array}$ \\
\hline 3 & Memiliki cita-cita dan rencana ke depan & & 60 \\
\hline 7 & Tidak mudah putus asa bila mengalami kegagalan & & 60 \\
\hline 14 & Menjalin relasi dengan konsumen/pelanggan & & 60 \\
\hline 4 & Memiliki rasa tanggungjawab dalam menjalankan usaha & & 57.5 \\
\hline 17 & Mengontrol produk yang dihasilkan & & 57.5 \\
\hline 10 & Prioritas yang jelas dalam menjalankan usaha & 60 & \\
\hline 9 & Merumuskan tujuan usaha dengan jelas & 57.5 & \\
\hline
\end{tabular}

Sumber : Hasil analisis data

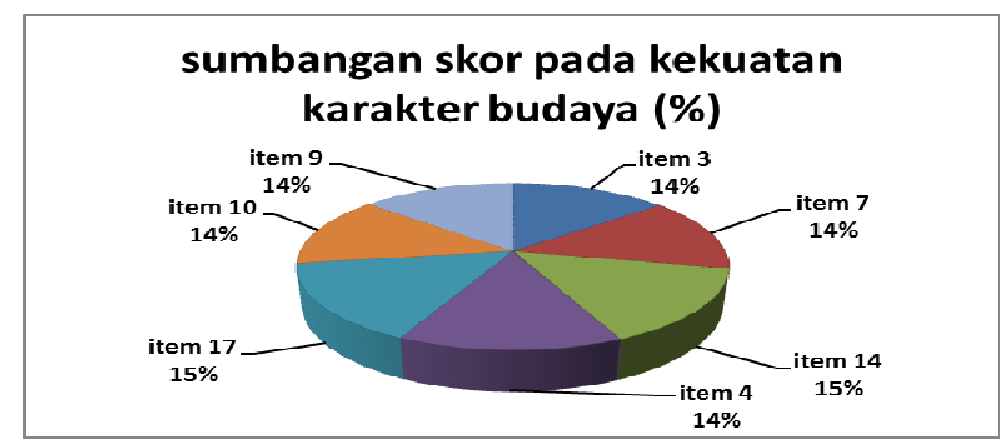

Gambar 2. Sumbangan Skor pada Kekuatan Karakter Budaya Sumber: Hasil analisis data 
Adakah titik lemah tentang karakteristik budaya ini? Memang ada meskipun tidak terlalu menonjol, yaitu pernyataan 'melaksanakan koordinasi dengan pengurus paguyuban usaha' dan 'kerjasama dengan pihak lain agar pekerjaan yang dilakukan lebih efisien'. Kemungkinan yang bisa diduga komunikasi di antara anggota paguyuban memang masih lemah dan organisasi paguyuban itu sendiri kurang berjalan dengan baik.

\section{Kemampuan Adaptasi.}

Pada era kemajuan teknologi dan informasi yang pesat dewasa ini menuntut para pengusaha kecil untuk menyesuaikan diri atau beradaptasi dengan lingkungan bisnis yang terus berkembang.Berdasarkan konsep, adaptasi meletakkan penekanan pada kemampuan organisasi untuk menerima, menafsirkan dan menerjemahkan gangguan dari lingkungan luar ke norma internal yang mengarah pada kelangsungan hidup atau kesuksesan.

Tabel 6. Kemampuan Adaptasi

\begin{tabular}{|c|c|c|c|c|c|c|}
\hline \multirow{2}{*}{ No } & \multirow{2}{*}{ Pernyataan } & \multicolumn{5}{|c|}{ Skala $1-5(\%)$} \\
\hline & & 1 & 2 & 3 & 4 & 5 \\
\hline 19 & $\begin{array}{l}\text { Berani mengambil risiko kegagalan untuk melakukan } \\
\text { hal baru }\end{array}$ & 0 & 7.5 & 25 & 47.5 & 20 \\
\hline 20 & $\begin{array}{l}\text { Ada kebutuhan akan perubahan dan cara baru dalam } \\
\text { berbisnis }\end{array}$ & 2,5 & 5 & 30 & 42,5 & 20 \\
\hline 21 & $\begin{array}{l}\text { Menjalankan bisnis dengan cara yang } \\
\text { fleksibel/luwes }\end{array}$ & 0 & 0 & 7,5 & 67,5 & 25 \\
\hline 22 & $\begin{array}{l}\text { Melakukan perubahan atas komentar dan saran } \\
\text { pelanggan }\end{array}$ & 0 & 2,5 & 22,5 & 47,5 & 33 \\
\hline 23 & Kesediaan untuk belajar dari pengalaman bisnis & 0 & 0 & 12,5 & 45 & 42,5 \\
\hline 24 & $\begin{array}{l}\text { Mengidentifikasi peluang baru karna lingkungan } \\
\text { usaha berubah }\end{array}$ & 2,5 & 5 & 22,5 & 47,5 & 22,5 \\
\hline 25 & $\begin{array}{l}\text { Tanggap terhadap para pesaing dan perubahan- } \\
\text { perubahan lain }\end{array}$ & 0 & 0 & 32,5 & 42,5 & 20 \\
\hline \multirow[t]{2}{*}{26} & $\begin{array}{l}\text { Mencoba memahami keinginan dan kebutuhan } \\
\text { pelanggan }\end{array}$ & 0 & 5 & 10 & 40 & 45 \\
\hline & $\begin{array}{l}\text { Rata-rata \%jawaban respondententang kemampuan } \\
\text { adaptasi }\end{array}$ & 0,6 & & 20,3 & 47,5 & 28,5 \\
\hline
\end{tabular}

Sumber : Hasil analisis data

Kriteria skala :

1. Tidak pernah melakukan (sangat buruk)

2. Jarang melakukan (buruk)

3. Kadang-kadang melakukan (cukup baik)

4. Sering melakukan (baik)

5. Selalu melakukan (sangat baik) 


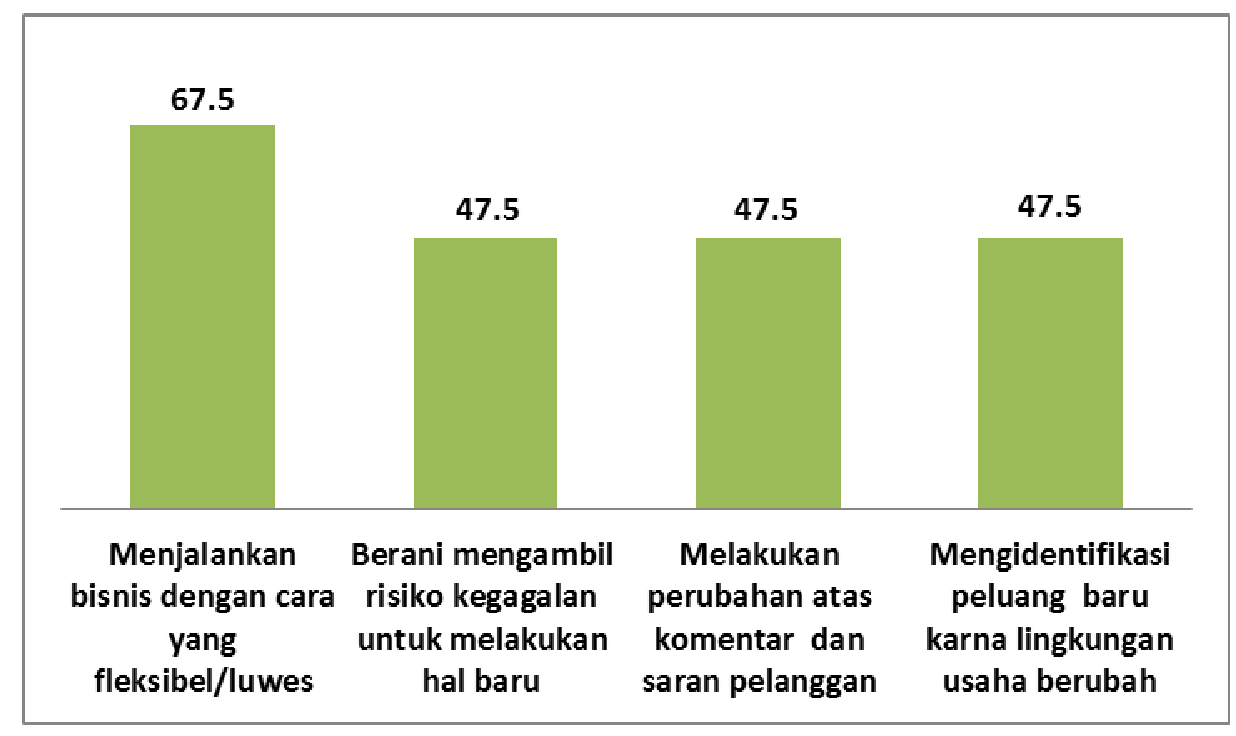

Grafik 1. Kemampuan Adaptasi yang Menonjol

Sumber: Hasil analisis data

Tiga aspek kunci dari kemampuan beradaptasi adalah persepsi dan respon terhadap lingkungan eksternal, kemampuan untuk menanggapi pelanggan internal dan reaksi cepat baik terhadap pelanggan internal maupun eksternal. Berdasarkan hasil penelitian, ternyata persepsi dan respon terhadap lingkungan eksternal ditunjukkan secara baik oleh responden dengan pilihan terbanyak ada pada skala 4 atau kriteria baik (lihat tabel 5).

Misalnya saja menjalankan bisnis dengan cara yang fleksibel/luwes memiliki angka terbesar di skala 4 sebesar 67.5 persen, sementara perilaku lainnya mendekati angka 50 persen, namun ada tiga hal yang mendekati angka 50, yaitu berani mengambil risiko kegagalan untuk melakukan hal baru, melakukan perubahan atas komentar dan saran pelanggan, mengidentifikasi peluang baru karna lingkungan usaha berubah masing-masing sebesar 47,5 persen. Secara rata-rata 47,5 persen responden memiliki kemampuan adaptasi pada skala 4 atau kriteria baik.

Menjalankan usaha dengan fleksibel/luwes adalah kekuatan utama usaha kecil dalam menghadapi konjungtur ekonomi eksternal yang kadang sulit diduga arahnya. Dan itulah yang menjadi sebeb mengapa usaha kecil umumnya mampu bertahan dalam berbagai tekanan ekonomi dan bahkan sering disebut-sebut sebagai penyelamat ekonomi Indonesia. Kemampuan adaptasi secara keseluruhan (lihat grafik 2) yang paling tinggi ada pada skala 4 sebesar 47,5 persen, berikutnya pada skala 5 sebesar 28.5 persen dan skala 3 sebesar 20.4 persen. 


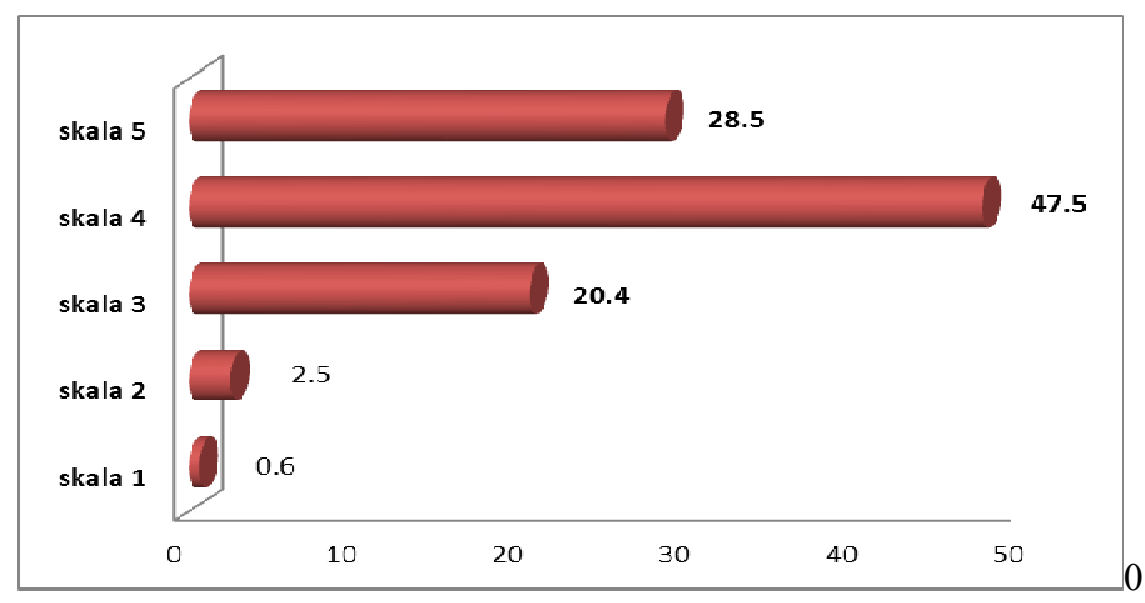

Grafik 2. Total Pilihan Responden terhadap Kemampuan Adaptasi di tiap Skala Sumber: Hasil analisis data

\section{Kinerja Usaha.}

Secara konseptual, ada banyak cara untuk mengetahui kinerja usaha, antara lain melalui laporan keuangan,sarana prasarana, inovasi produk, target pasar, pelatihan SDM, dan sebagainya.Namun dalam penelitian ini akan dibatasi pada tingkat persepsi para pemilik usaha kecil tentang kemajuan usaha mereka dari sisi hasil yang diperoleh.

Tabel 7. Kinerja Usaha

\begin{tabular}{|c|l|c|c|c|c|c|}
\hline \multirow{2}{*}{ No } & \multicolumn{5}{|c|}{ Pernyataan } & \multicolumn{5}{c|}{ Skala 1 - 5 } \\
\cline { 3 - 6 } 27 & $\begin{array}{l}\text { Beberapa tahun terakhir ini hasil penjualan dari bisnis } \\
\text { cenderung }\end{array}$ & 0 & 2.5 & 32.5 & 52.5 & 12.5 \\
\hline 28 & $\begin{array}{l}\text { Beberapa tahun terakhir ini keuntungan/laba yang } \\
\text { diperoleh cenderung }\end{array}$ & 0 & 0 & 32.5 & 57.5 & 10 \\
\hline 29 & $\begin{array}{l}\text { Dibanding para pengrajin lain di sekitar sini, kinerja } \\
\text { (penjualan, laba, dsb) }\end{array}$ & 0 & 0 & 37.5 & 50 & 12.5 \\
\hline 30 & $\begin{array}{l}\text { Apabila ada kesempatan, minat untuk beralih ke } \\
\text { bidang/pekerjaan lain demi memperoleh penghasilan } \\
\text { yang lebih baik }\end{array}$ & 10 & 20 & 30 & 27.5 & 12.5 \\
\hline & Rata-rata \% jawaban responden terhadap kinerja usaha & 2,5 & 6,6 & 30 & 50 & 10 \\
\hline
\end{tabular}

Sumber: Hasil analisis data

Keterangan skala:

1. Sangat menurun

2. Menurun

3. Kurang lebih tetap

4. Meningkat

5. Sangat meningkat 


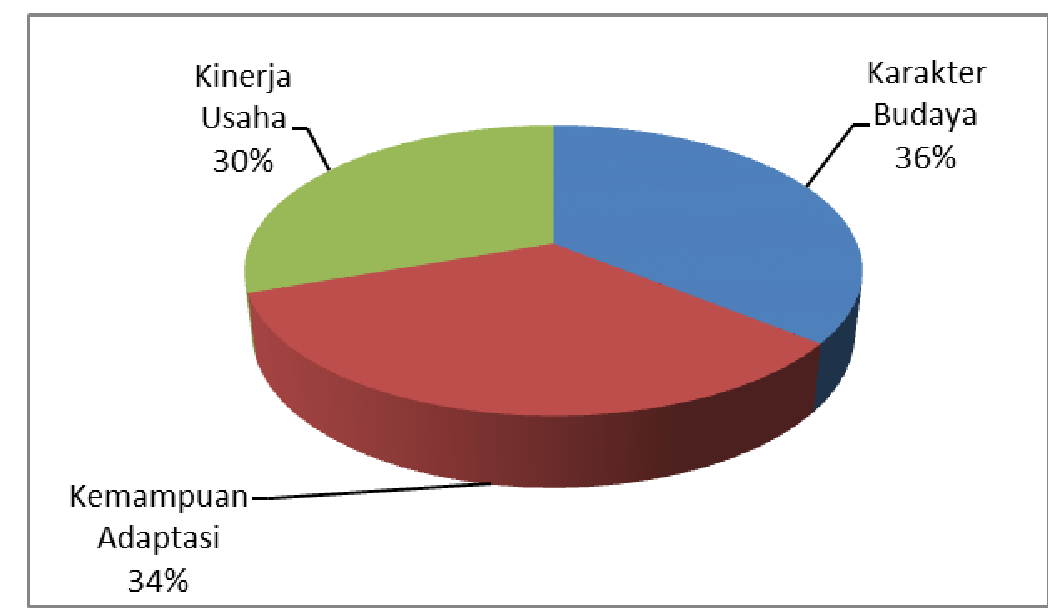

Grafik 3. Skor Variabel (\%) Karakter Budaya, Adaptasi dan Kinerja Sumber: Hasil analisis data

Berdasarkan hasil penelitian ada tiga hal yang cukup menonjol menurut persepsi para pengusaha kecil, yaitu penjualan yang terus meningkat (skala 4) dijawab oleh responden sebesar 52,5 persen, laba yang meningkat 57,5 persen, dan kinerja meningkat sebesar 50 persen. Secara rata-rata sebesar 50 persen menjawab pada skala 4 (kinerja meningkat). Secara umum skor yang diperoleh dari tiga variable karakter budaya, kemampuan adaptasi dan kinerja usaha dapat dilihat pada diagram.

\section{Kekuatan Korelasi}

Berdasarkan perhitungan non-parametric correlations rank Spearman, korelasi antara karakteristik budaya dan kemampuan adaptasi sebesar 0,653 signifikan pada tingkat 0,01 uji dua ekor. Angka ini menurut interpretasi korelasi masuk dalam kriteria kuat (antara 0,6-0,79). Berikutnya korelasi antara kemampuan adaptasi dan kinerja usaha memiliki angka korelasi 0,469 signifikan pada tingkat 0,01 uji dua ekor dan tergolong cukup kuat (antara 0,4-0,59), sedangkan korelasi antara karakteristik budaya dan kinerja usaha sebesar 0,467.

Hasil korelasi itu menggambarkan bahwa karakteristik budaya, kemampuan adaptasi dan kinerja usaha saling terkait. Oleh karena itu usaha apa pun untuk meningkatkan kinerja usaha kecil hendaknya memperhatikan budaya dan kemampuan adaptasi mereka terhadap perkembangan bisnis. 
Tabel 8. Non-parametric Correlations antara karakteristik Budaya, Kemampuan Adaptasi dan Kinerja Usaha

\begin{tabular}{|c|c|c|c|c|c|}
\hline & & & kar.bud & adaptasi & kinerja \\
\hline \multirow[t]{9}{*}{ Spearman's rho } & \multirow[t]{3}{*}{ kar.bud } & Correlation Coefficient & 1.000 & $.653^{* *}$ & $.467^{* * *}$ \\
\hline & & Sig. (2-tailed) & & .000 & .002 \\
\hline & & $\mathrm{N}$ & 40 & 40 & 40 \\
\hline & \multirow[t]{3}{*}{ adaptasi } & Correlation Coefficient & $.653^{* *}$ & 1.000 & $.469^{* *}$ \\
\hline & & Sig. (2-tailed) & .000 & & .002 \\
\hline & & $\mathrm{N}$ & 40 & 40 & 40 \\
\hline & \multirow[t]{3}{*}{ kinerja } & Correlation Coefficient & $.467^{* *}$ & $.469^{* *}$ & 1.000 \\
\hline & & Sig. (2-tailed) & .002 & .002 & \\
\hline & & $\mathrm{N}$ & 40 & 40 & 40 \\
\hline
\end{tabular}

**. Correlation is significant at the 0.01 level (2-tailed).

Sumber: Hasil analisis data

\section{KESIMPULAN DAN SARAN}

\section{Simpulan}

Hasil penelitian ini menghasilkan kesimpulan seperti berikut ini. Sebesar 44.2 persen dari responden memiliki karakteristik budaya berada pada skala 4 (kuat) dan 41.5 persen pada skala 5 (sangat kuat). Persepsi dan respon terhadap lingkungan eksternal ditunjukkan secara baik oleh responden dengan pilihan terbanyak ada pada skala 4 atau tergolong dalam kriteria baik. Secara rata-rata sebesar 50 persen dari responden menjawab pada skala 4 atau kinerja meningkat. Ada korelasi kuat antara tiga variabel karakter budaya, kemampuan adaptasi dan kinerja usaha.

\section{Saran}

Saran-saran terkait hasil penelitian ini adalah seperti berikut ini. Perlunya upaya peningkatan komunikasi, koordinasi dan kerja sama para pemilik usaha dalam paguyuban. Penyuluhan/bimbingan dapat dilakukan melalui program kerja KKP Fakultas Ekonomi. Perlu dilakukan penelitian secara khusus dan mendalam tentang strategi-strategi peningkatan kinerja usaha dengan memperhatikan empat perspektif balanced scorecard yaitu perspektif keuangan, perspektif pelanggan, perspektif proses bisnis internal dan perspektif pertumbuhan.

\section{DAFTAR REFERENSI}

Anderson, G.M., Anderson , M.J., dan Lee, J.B. (2015). Defining corporate culture, NACDonline.org. 
Coleman, John. (2013). Six components of a great corporate culture. https://hbr.org/2013/05/six-components-of-culture.

Denison, Daniel R. (1995). Toward a theory of organizational culture and effectiveness. http://www.trustiseverything.com/wpcontent/uploads/2012/07/denison-mishra-toward-a-theory-of-org-cultureand-effect-org-sci-1995.pdf.

Flynn, F.J., \& Chatman, J. A. (2001). Strong cultures and innovation: Oxymoron or opportunity? In C. L. Cooper,S. Cartwright, \& P. C. Earley (Eds.), International handbook of organizational culture and climate (pp. 263287)., New York: John Wiley \& Sons.

Guiso, L., Sapienza, P., dan Zingales, L.(2013). The value of corporate culture, NBER, \& CEPR, September.

Half, R. (2016). The role of corporate culture in small business. Management Resources on Thursday, July 28, https://www.roberthalf.com/managementresources.

Heskett, James L. (2011). The culture cycle: The profit power of corporate culture. UPS Foundation Professor of Business Logistics, Emeritus. http://hbswk.hbs.edu/item/6818.html.

Jaghargh, F.Z., Ghorbanpanah, H., Nabavi, S.E., Saboordavoodian, A., dan Farvardin, Z.(2012). A survey on organizational culture based on Stephan Robbins's theory (Case Study), 2nd International Conference on Management and Artificial Intelligence IPEDR Vol.35 (2012) (C) (2012) IACSIT Press, Singapore.

Jatmiko, R.D., dkk. (2008). Kinerja usaha kecil berbasis strategi bisnis, budaya organisasi, dan kepribadian pemilik.

Johnson, J. J., \& McIntyre, C. L. (1998). Organizational culture and climate correlates of job satisfaction, Psychological Reports, 82, 843-850.

Kotter, John P., dan Heskett, J.L. (1997). Corporate culture and performance, dampak budaya perusahaan terhadap kinerja. PT Prenhalindo.

MacDonald, S. (2012). 4 ways to keep a small company culture as your business grows. http://www.entrepreneur.com/author/stuart-macdonald

MacIntosh, Eric W. \& Doherty, A. (2010). The influence of organizational culture on job satisfaction and intention to leave, Sport Management Review 13, 106117 available at ScienceDirect.

Marchand, Allison Nadine. (2013). What is an adaptive organisational culture? https://www.scribd.com/document/154646210/Adaptive-Culture 
Miller, Rick. (2013). 10 ways to build an adaptive culture in your organization. http://www.vistage.com/blog/leadership/10-ways-to-build-an-adaptiveculture-in-your-organization/.

Nesbit, P.L., dan Lam, E. (2014). Cultural adaptability and organizational change: A case study of a social service organization in Hong Kong. Contemporary Management Research, Pages 303-324, Vol. 10, No. 4, December 2014.

O’Donnell, O., \& Boyle,R. (2008). Understanding and managing organisational culture. CPMR Discussion Paper 40.

Paunovic, S., dan Dima, I.C. (2014). Organizational culture and corporate entrepreneurship, Annals of the University of Petroşani, Economics, 14(1), 2014, 269-276.

Ramadan, Wael H. (2010). The Influence of organizational culture on sustainable competitive advantage of small \& medium sized establishments, Sheridan Institute of Technology \&Advanced Learning, E-Leader Budapest.

Rasmussen, Sara. (2013). Organisational culture in innovative small to medium sized enterprises (SMEs), Master of Science Thesis INDEK 2013:126, KTH Industrial Engineering and Management Industrial Management SE-100 44 STOCKHOLM.

Robbin, P Stephen. (2003). Essential of organizational behavior. (7th Edition). ISBNO-A13-035309-4. Upper Saddle River, N.J Prentice Hall.

Shahzad, Fakhar. (2012). Impact of organizational culture on organizational performance: An overview, Interdisciplinary Journal Of Contemporary Research In Business, January 2012, VOL 3, NO 9.

Schein, E.H. (2010). Organizational culture and leadership. Jossey-Bass, A Wiley Imprint, Third Edition. http://my.safaribooksonline.com/book/leadership/9780470190609.

Tharp, B.M. (2009). Defining "culture" and "organizational culture": From Anthropology to the Office, Haworth. http://www.thercfgroup.com/files/resources/Defining-Culture-andOrganizationa-Culture_5.pdf.

Tharp, B.M. (2017). Four organizational culture types, Haworth http://www.academia.edu/1588713/Four_Organizational_Culture_Types.

Udrescu, M., Coderie, C, dan Grabara, J.K. (2012). Change management in the organizational culture of small and medium enterprises, Czestochwska University, Poland. 